\title{
PERIPHERAL VASCULAR EFFECT OF CORTISONE IN RHEUMATOID ARTHRITIS, SCLERODERMA, AND OTHER RELATED CONDITIONS
}

\author{
BY \\ B. N. CATCHPOLE, R. P. JEPSON, and J. H. KELLGREN \\ From the University Department of Surgery and Rheumatism Research Centre, \\ Manchester Royal Infirmary
}

(RECEIVED FOR PUBLICATION JULY 9, 1954)

Many systemic diseases including rheumatoid arthritis are frequently associated with a diminution or redistribution of peripheral blood flow. This may be due to an organic arterial narrowing or occlusion or, alternatively, to a high resting tone in the peripheral vessels which may still be capable under certain conditions of relaxing to a normal calibre. Thus the vasodilatation in the fingers which normally follows heating of the trunk and legs was shown by Vulliamy (1952) to be absent in ten out of eleven cases of pink disease. Clinical recovery was associated with a return of this vasodilator response. A similar vasomotor defect was demonstrated by Woodmansey (1951) in cases of rheumatoid arthritis. Beattie and Woodmansey (1953) later showed that peripheral vasodilator response to heating in such cases could frequently be increased by an intravenous infusion of ACTH. Hines (1950) reported similar findings in three patients with acrosclerosis treated by cortisone.

The study reported in this paper concerns patients suffering from rheumatoid arthritis and other chronic systemic diseases in whom the fingers appeared cold and cyanosed with Raynaud's phenoo menon or acrocyanosis on exposure to cold. II some patients nutritional lesions such as pulp

TABLE

PARTICULARS OF 22 PATIENTS INVESTIGATED

\begin{tabular}{|c|c|c|c|c|c|c|c|c|c|c|c|c|c|c|}
\hline \multirow{4}{*}{ Diagnosis } & \multirow{4}{*}{$\begin{array}{l}\text { Case } \\
\text { No. }\end{array}$} & \multirow{4}{*}{ Sex } & \multirow{4}{*}{$\begin{array}{c}\text { Age } \\
\text { (yrs) }\end{array}$} & \multirow{4}{*}{$\underset{(y r s)}{\text { Duration }}$} & \multirow{4}{*}{$\begin{array}{l}\text { Differ- } \\
\text { ential } \\
\text { Sheep cell } \\
\text { Aggluti- } \\
\text { nation } \\
\text { Test }\end{array}$} & \multirow{4}{*}{$\begin{array}{l}\text { Erythro- } \\
\text { cyte } \\
\text { Sedimen- } \\
\text { tation } \\
\text { Rate } \\
(\mathrm{mm} . / \mathrm{hr})\end{array}$} & \multirow{4}{*}{$\begin{array}{c}\begin{array}{c}\text { Delay } \\
\text { of } \\
\text { Flush } \\
\text { after } \\
\text { Occlusion } \\
\text { (sec.) }\end{array}\end{array}$} & \multicolumn{7}{|c|}{ Response to Cortisone } \\
\hline & & & & & & & & \multirow{3}{*}{$\begin{array}{l}\text { General } \\
\text { Clinical }\end{array}$} & \multicolumn{6}{|c|}{ Circulatory (galvanometer reading)* } \\
\hline & & & & & & & & & \multicolumn{2}{|c|}{ Resting } & \multicolumn{2}{|c|}{$\begin{array}{l}\text { Reactive } \\
\text { Hyperaemia }\end{array}$} & \multicolumn{2}{|c|}{$\begin{array}{l}\text { Body } \\
\text { Heating }\end{array}$} \\
\hline & & & & & & & & & (a) & (b) & (a) & (b) & (a) & (b) \\
\hline$\underset{\substack{\text { I } \\
\text { Arthritis }}}{\text { Rheumatoid }}$ & $\begin{array}{l}1 \\
2 \\
3 \\
4 \\
5 \\
6 \\
7\end{array}$ & $\begin{array}{l}\mathbf{F} \\
\mathbf{F} \\
\mathbf{F} \\
\mathbf{M} \\
\mathbf{F} \\
\mathbf{F} \\
\mathbf{M}\end{array}$ & $\begin{array}{l}29 \\
53 \\
42 \\
55 \\
46 \\
57 \\
31\end{array}$ & $\begin{array}{c}3 \\
14 \\
1 \frac{1}{2} \\
8 \\
3 \\
2 \\
8\end{array}$ & $\begin{array}{l}\text { Positive } \\
\text { Positive } \\
\text { Positive } \\
\text { Positive } \\
\text { Positive } \\
\text { Negative } \\
\text { Negative }\end{array}$ & $\begin{array}{l}35 \\
45 \\
90 \\
80 \\
20 \\
70 \\
80\end{array}$ & $\begin{array}{l}<4 \\
<4 \\
<4 \\
<4 \\
<4 \\
<4 \\
<4\end{array}$ & $\begin{array}{l}++ \\
++ \\
++ \\
++ \\
+ \\
+ \\
++\end{array}$ & $\begin{array}{r}6 \\
3 \\
2 \\
7 \\
-2 \\
0 \\
35\end{array}$ & $\begin{array}{r}18 \\
130 \\
65 \\
116 \\
25 \\
5 \\
69\end{array}$ & $\begin{array}{r}6 \\
16 \\
33\end{array}$ & $\begin{array}{l}32 \\
15 \\
68\end{array}$ & $\begin{array}{l}95 \\
15 \\
51\end{array}$ & $\begin{array}{l}55 \\
15 \\
70\end{array}$ \\
\hline $\begin{array}{c}\text { II } \\
\begin{array}{c}\text { Non-Articular } \\
\text { Rheumatoid } \\
\text { Disease }\end{array}\end{array}$ & $\begin{array}{r}8 \\
9 \\
10 \\
11 \\
12\end{array}$ & $\begin{array}{l}\mathbf{F} \\
\mathbf{F} \\
\mathbf{F} \\
\mathbf{F} \\
\mathbf{F}\end{array}$ & $\begin{array}{l}28 \\
41 \\
25 \\
48 \\
34\end{array}$ & $\begin{array}{l}7 \\
3 \\
1 \\
2 \\
3 \frac{1}{2}\end{array}$ & $\begin{array}{l}\text { Positive } \\
\text { Positive } \\
\text { Negative } \\
\text { Positive } \\
\text { Positive }\end{array}$ & $\begin{array}{r}55 \\
15 \\
2 \\
20 \\
20\end{array}$ & $\begin{array}{r}4 \\
4 \\
15 \\
4\end{array}$ & $\begin{array}{l}+ \\
+ \\
\mathbf{o} \\
\mathbf{0} \\
+\end{array}$ & $\begin{array}{r}10 \\
0 \\
2 \\
10 \\
4\end{array}$ & $\begin{array}{r}85 \\
22 \\
0 \\
7 \\
8\end{array}$ & $\begin{array}{r}14 \\
21 \\
1 \\
4\end{array}$ & $\begin{array}{r}90 \\
34 \\
3 \\
\\
21\end{array}$ & $\begin{array}{r}47 \\
47 \\
3 \\
35\end{array}$ & $\begin{array}{r}104 \\
60 \\
7 \\
62 \\
\end{array}$ \\
\hline $\begin{array}{l}\text { III } \\
\text { Systemic } \\
\text { Sclerosis }\end{array}$ & $\begin{array}{l}13 \\
14 \\
15\end{array}$ & $\begin{array}{l}\mathbf{F} \\
\mathbf{F}\end{array}$ & $\begin{array}{l}21 \\
24 \\
53\end{array}$ & $\begin{array}{r}8 \\
13 \\
3\end{array}$ & $\begin{array}{l}\text { Positive } \\
\text { Positive } \\
\text { Negative }\end{array}$ & $\begin{array}{l}25 \\
50 \\
34\end{array}$ & $\begin{array}{r}>30 \\
>30 \\
5\end{array}$ & $\begin{array}{l}\mathbf{0} \\
\mathbf{o} \\
\mathbf{0}\end{array}$ & $\begin{array}{r}0 \\
0 \\
-1\end{array}$ & $\begin{array}{r}0 \\
0 \\
-4\end{array}$ & $\begin{array}{l}0 \\
0 \\
2\end{array}$ & $\begin{array}{r}3 \\
0 \\
-4\end{array}$ & $\begin{array}{r}0 \\
0 \\
23\end{array}$ & $\begin{array}{r}6 \\
0 \\
32\end{array}$ \\
\hline 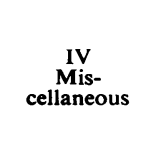 & $\begin{array}{l}16 \\
17 \\
18 \\
19 \\
20 \\
21 \\
22\end{array}$ & $\begin{array}{l}\mathbf{F} \\
\mathbf{F} \\
\mathbf{M} \\
\mathbf{M} \\
\mathbf{F} \\
\mathbf{F} \\
\mathbf{F}\end{array}$ & $\begin{array}{l}38 \\
30 \\
40 \\
36 \\
51 \\
48 \\
37\end{array}$ & $\begin{array}{c}22 \\
6 \\
8 \\
2 \frac{1}{2} \\
2 \\
20 \\
6\end{array}$ & $\begin{array}{l}\text { Positive } \\
\text { Positive } \\
\text { Positive } \\
\text { Negative } \\
\text { Negative } \\
\text { Negative } \\
\text { Negative }\end{array}$ & $\begin{array}{r}30 \\
11 \\
40 \\
30 \\
20 \\
20 \\
3\end{array}$ & $\begin{array}{r}5 \\
>10 \\
25 \\
10 \\
<4 \\
>\quad 5 \\
>8\end{array}$ & $\begin{array}{l}\mathbf{0} \\
\mathbf{o} \\
\mathbf{0} \\
+ \\
+ \\
+ \\
+\end{array}$ & $\begin{array}{r}-7 \\
0 \\
0 \\
5 \\
2 \\
2 \\
0\end{array}$ & $\begin{array}{r}4 \\
0 \\
1 \\
55 \\
30 \\
2 \\
25\end{array}$ & $\begin{array}{r}-6 \\
0 \\
4 \\
14 \\
15 \\
2 \\
0\end{array}$ & $\begin{array}{r}18 \\
0 \\
1 \\
42 \\
42 \\
6 \\
33\end{array}$ & $\begin{array}{r}24 \\
0 \\
11 \\
15 \\
79 \\
10 \\
31\end{array}$ & $\begin{array}{r}28 \\
0 \\
1 \\
75 \\
104 \\
46 \\
48\end{array}$ \\
\hline
\end{tabular}

* (a) before treatment (b) during treatment. 
ulcers or soft tissue atrophy were also present. An attempt was made to assess the degree and duration of their peripheral vascular response to cortisone therapy in terms of changes in digital blood flow estimated by a heat flow disk calorimetric technique and to correlate this response with the underlying disease process, other vascular and nonvascular tests, and the general therapeutic response of the patient to cortisone.

\section{Patients Studied}

The particulars of 22 in-patients investigated are set out in the Table. It will be noted that they have been grouped into four main diagnostic categories, though for many of the patients in Group IV no really satisfactory diagnostic label could be found.

Group I.-Seven patients considered to be suffering from typical rheumatoid arthritis by reason of their clinical and radiological joint lesions, a persistently raised erythrocyte sedimentation rate and in five a positive differential sheep cell agglutination test (D.A.T.).

Group II.-Five patients considered to be suffering from non-articular rheumatoid disease, who gave a history of limb pains with morning stiffness but without significant clinical or radiological changes in the joints. They had, however, marked nodular thickening of the long flexor tendons in the hands and in four of the five cases the D.A.T. was positive. In at least two patients (Cases 9 and 11) there was also definite sclerosis of the extremities.

Group III.-Three patients with established systemic sclerosis: that is, slowly progressive sclerosis and atrophy of the extremities associated with multiple joint and visceral lesions.

Group IV.-A miscellaneous group of seven patients, three considered to be suffering from dermatomyositis and its sequelae (Cases 19, 20, and 21), one from classical scleroderma of the trunk and limbs (Case 22), and three from multiple occlusive lesions in the small vessels of unknown aetiology associated with sclerosis of the extremities (Cases 16, 17, and 18).

If the term scleroderma is employed in its widest sense, it could be applied to all the patients in Groups III and IV and to at least two of the patients in Group II.

\section{Methods}

Estimations of finger blood flow were made before cortisone therapy was initiated:

(1) with the patient resting,

(2) after the application of a supra-systolic pneumatic cuff for $5 \mathrm{~min}$. to the upper arm,

(3) after body heating.

These recordings were repeated after the administration of cortisone for $72 \mathrm{hrs}$ (50 mg. 6-hrly), and finally 5 to 7 days after cessation of the cortisone therapy. In a few patients, however, cortisone therapy was continued for several months.

Modifications of finger blood flow were assessed by means of a copper-tellurium disk (Hatfield, 1950; Catchpole and Jepson, 1954). The disk, which has a diameter varying from $0.5-1 \cdot 0 \mathrm{~cm}$. and a thickness of 2-3 mm., consists of tellurium alloy covered on both faces by copper gauze. Leads from the faces of the disk connect with a mirror galvanometer $(450 \mathrm{ohm})$. When one surface of the disk is maintained at a constant temperature, the potential difference which arises between the two faces of the disk allows the heat flow across the disk to be calculated in calories per unit area per unit time. Alternatively the disk may be used as a thermocouple, and under the conditions used in these experiments a temperature difference between the faces of $2.5^{\circ} \mathrm{C}$. was equivalent to approximately 100 galvanometer divisions.

The disk was attached to the skin over the pulp of a finger with thin cellulose tape covered by a fine rubber finger stall, and the digit was immersed in a continuously stirred water bath, the temperature of which was maintained at $30^{\circ} \mathrm{C}$. Readings were made from the galvanometer at minute or halfminute intervals. Conditions for each experiment were standardized, the subject resting lightly clothed on a couch in a draughtless temperature-controlled $\left(21^{\circ} \mathrm{C} . \pm \frac{1}{2}^{\circ}\right)$ room for at least $45 \mathrm{~min}$. before the readings were begun. After the establishment of basal heat flow recordings, a reactive hyperaemia was induced by the application of a pneumatic tourniquet to the upper arm $(50 \mathrm{~mm}$. $\mathrm{Hg}$ above systolic blood pressure) for $5 \mathrm{~min}$. Peripheral vasodilatation was obtained by heating the trunk and limbs of the patient, excluding the arm to be measured, with an electric blanket for $45 \mathrm{~min}$.

This disk technique provides a useful index of finger blood flow which is particularly suitable for comparative studies of vascular responsiveness. Although figures for heat flow per unit area and time can be calculated from the galvanometer readings, they do not provide a more accurate index of blood flow changes than the original readings, so that these have been used throughout. Fig. 1 (overleaf), showing the records obtained from Case 1, serves to illustrate the nature of the data collected.

The presence or absence of organic disease of the digital arteries was assessed by a reactive hyperaemia timing test (Pickering, 1933), in which the hand was immersed to the wrist in water at $40^{\circ} \mathrm{C}$. for $5 \mathrm{~min}$., during which time a supra-systolic cuff was applied to the upper arm. On removal of the cuff the time taken for the resulting hyperaemia flush to reach the tips of the digits was estimated. An interval of 


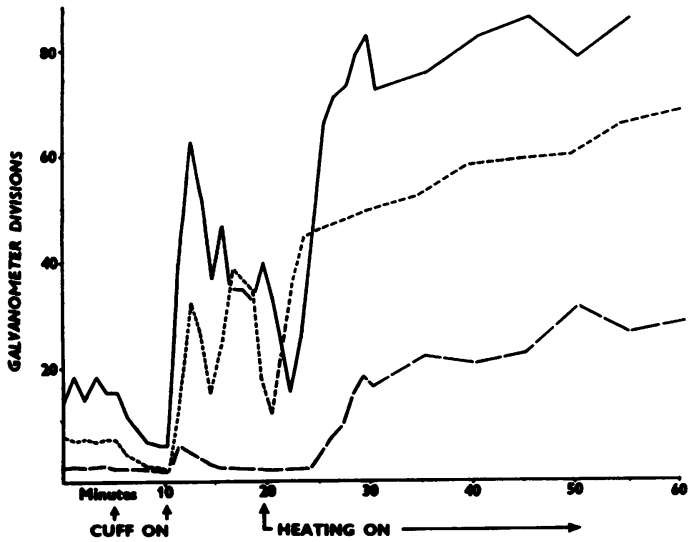

Fig. 1.-Recordings of finger skin heat flow in galvanometer divisions (Case 1).

: before cortisone.

........... during cortisone.

_ - : 7 days after cessation of cortisone.

$4 \mathrm{sec}$. or less was taken as evidence of normal digital artery patency.

The general response of the patient to cortisone therapy in terms of symptomatic relief, improvement of functional capacity, and increased joint mobility was assessed and graded as nil $(0)$, slight $(+)$, or good $(++)$. The erythrocyte sedimentation rate was estimated by the Westergren technique, and the differential sheep cell agglutination test by the method of Ball (1950).

\section{Results}

Group I (Rheumatoid Arthritis: 7 patients).-The seven patients in this group had normal digital artery patency as estimated by the reactive hyperaemia test. During the disk measurements at rest, the finger temperature was no higher than the water temperature in two, slightly higher in four, and definitely higher in one. In the five patients investigated by the reactive hyperaemia disk test, vasodilation following occlusion was present but of slight degree and duration, and these patients all showed a somewhat reduced peripheral vascular response to body heating. The administration of cortisone caused a marked increase of the resting blood flow and a greater quantitative response to temporary ischaemia. It was also noticed that the records reflected extraneous stimuli such as noise and conversation, indicating a generally more labile vasomotor state. These patients generally had a good clinical response to cortisone, as estimated by the sense of well-being, loss of pain, and freedom and strength of movement. After the withdrawal of the cortisone there was a deterioration in the general condition of the patients and a coincident reduction of the resting digital blood flow below the precortisone level. In addition, the hyperaemia following temporary occlusion and body heating was markedly decreased (Fig. 1).

Group II (Non-Articular Rheumatoid: 5 patients).There was some general and vascular response to cortisone therapy in three patients in whom the reactive hyperaemia timing test was at the upper limit of normal. Two patients (Cases 9 and 11), whose reactive hyperaemia time was delayed and who did not experience general improvement with the drug, also failed to manifest an improved peripheral blood flow. The "rebound" after cessation of therapy was similar to that in Group I.

Group III (Systemic Sclerosis: 3 patients).-These patients had evidence of gross organic arterial occlusion as demonstrated by the delayed reactive hyperaemia time, nutritional ulcers, and soft tissue atrophy of the extremities. During the heat flow disk test the finger temperature remained equal to that of the water bath $\left(30^{\circ} \mathrm{C}\right.$.) and only in Case 15 did the 5 -min. ischaemia or the body heating provoke a slight digital vasodilatation. The vascular reactions and the general and articular symptoms of these patients were not appreciably modified bs cortisone therapy.

Group IV (Miscellaneous: 7 patients).-On patient in this group (Case 20) had a normal reactive hyperaemia time and showed a good circulatory and moderate general response to cortisone therapy. The other six had a delayed reactive hyperaemia time which varied from 5-25 sec. In general, the finger temperature on immersion was near that of the water bath. During cortisone therapy some change in blood flow was detected in those whose reactive hyperaemia was delayed less than $10 \mathrm{sec}$., but no change could be detected in the two (Cases 17 and 18) whose reactive hyperaemia was greater than $10 \mathrm{sec}$. A slight general symptomatic improvement was noted in four of the five patients showing vasodilatation during cortisone therapy.

The mean circulatory findings in the first three groups both before and during cortisone are illustrated in Fig. 2 (opposite). The findings in six normal individuals have been included for comparison.

\section{Discussion}

Recording of skin temperature by the heat flow disk technique does not allow absolute assessment of blood flow to be made. It does, however, provide a useful index of fluctuations or changes in cutaneous blood flow (Catchpole and Jepson, 1954). It is more satisfactory than the copper-constantum

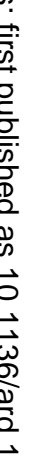



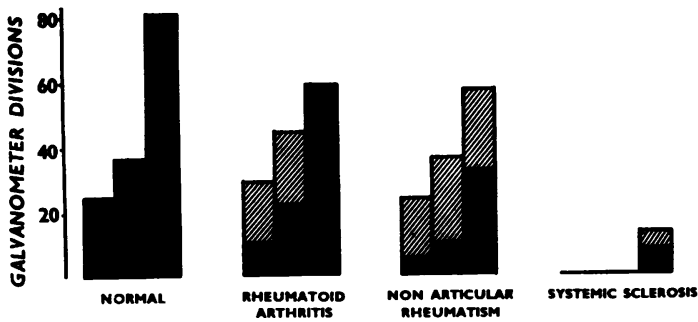

Fig. 2.--Mean values of finger skin heat flow in six normal subjects and in the patients listed in the Table. Solid: before cortisone.

Left: resting level.

Hatched: during cortisone.

Centre: maximal heat flow following 5 minutes' occlusion

Right: maximal heat flow during 45 minutes' body heating.

thermocouple technique, in that the test finger is kept in constant temperature water bath.

The patients reported in this study fall into two main groups: those who responded to cortisone therapy by a peripheral vasodilatation, and those who failed to respond.

In the former group evidence of increased peripheral blood flow was obtained from the higher resting temperature and the greater response to the vasodilator stimuli of ischaemia and trunk heating. This was accompanied in most instances by a diminution of articular pain and an improvement in strength and mobility.

The relationship between the circulatory response to cortisone and the state of the peripheral arterial tree as judged by the reactive hyperaemia timing test is shown in Fig. 3. It will be seen that a marked increase of digital blood flow during cortisone therapy only occurred when the reactive hyperaemia appeared in less than $5 \mathrm{sec}$. When the delay in this test was longer than $10 \mathrm{sec}$. cortisone had no effect whatsoever. Furthermore, those patients who experienced marked symptomatic relief from cortisone all showed some increase of digital blood flow, whereas those who experienced no symptomatic relief also showed no change in digital blood flow. Among the patients who obtained partial symptomatic relief from cortisone there were several who showed a large increase of finger blood flow and several in whom this was negligible or absent.

On the other hand, the presence of a positive differential sheep cell agglutination test did not appear to be associated with a good circulatory response to cortisone. Thus, of the fourteen patients in whom this test was positive, seven showed little or no increase of digital blood flow during cortisone therapy, but of the eight in whom the test was negative three showed a substantial increase.

The withdrawal of cortisone is known to cause a deterioration in the well-being of the patient, and

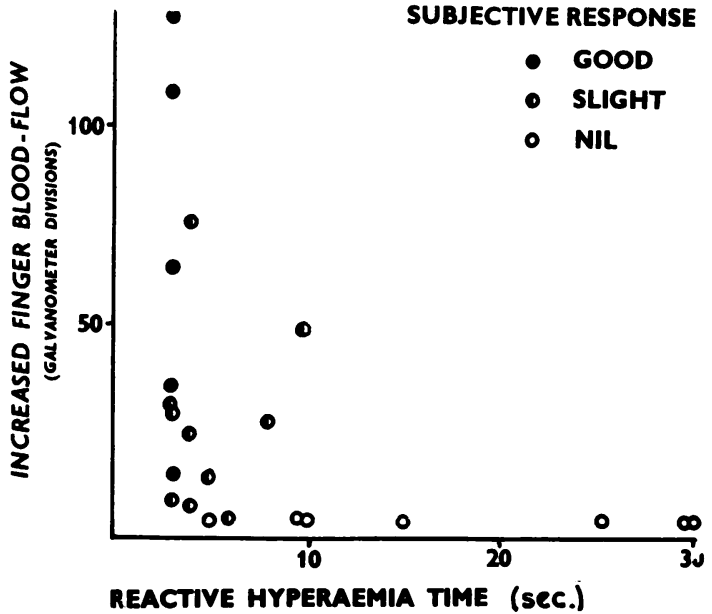

Fig. 3.-Relationshıp between reactive hyperaemia time, increase of resting heat flow during cortisone therapy, and subjective response to cortisone therapy in terms of relief of joint pain and stiffness. Each circle represents one patient.

is often accompanied by a return of previous joint pain and stiffness. A similar "rebound" was exhibited by the finger blood flow, which invariably diminished to below the pre-cortisone level.

The disturbance of the peripheral circulation in rheumatoid arthritis and some related conditions is peculiar, in that cold mauve extremities are associated with hot joints. After cortisone therapy or intra-articular hydrocortisone, the abnormally high joint temperature falls (Hollander and others, 1951). Plethysmographic studies of blood flow through the knee segment (Janus, 1952) have confirmed the increased knee blood flow in rheumatoid disease and have demonstrated that during cortisone or ACTH therapy this high knee blood flow falls towards normal levels at a time when finger blood flow is increasing; thus we are dealing with an abnormal distribution of blood flow in the limbs of these patients rather than a total increase or decrease. The mechanism by which this redistribution is brought about is unknown, but in patients with rheumatoid arthritis uncomplicated by occlusive arterial disease sympathectomy produces warm, dry extremities, although it does not relieve the arthritis. This suggests that the redistribution of the peripheral circulation in these patients is probably not a causal but a secondary phenomenon. The mechanism by which cortisone influences the peripheral circulation in these patients is equally unknown, but in one patient (Case 17), in whom a cervico-thoracic sympathetic ganglionectomy was performed, a course of cortisone given 3 months after the operation failed to provoke the moderate peripheral vasodilatation which was recorded before the operation. 
This suggests that the peripheral vascular action of cortisone may, like nor-adrenaline (Barcroft and others, 1954), depend on the integrity of the sympathetic nervous system as well as on the patency of the peripheral vessels.

A disappointing finding was the complete absence of response to the short course of cortisone in the three patients with systemic sclerosis, the poor clinical response in most of the patients considered to have non-articular rheumatoid disease, and the complete absence of any improvement in peripheral circulation in two of these latter patients. In the miscellaneous group only those patients considered to be suffering from subacute dermatomyositis obtained some slight symptomatic relief from cortisone, and these also showed some improvement in their peripheral circulation. It was thought that more prolonged cortisone therapy might be more effective, and four patients (Cases 13, 14, 16, and 19) were given oral cortisone in a dosage of $100 \mathrm{mg}$. per day for periods of 1 to 3 months, but in none of these was there any further change. One of these patients (Case 16) developed fatal right heart failure. Autopsy material from this patient and biopsy material from Case 14 showed that the lumen of many smaller arteries was greatly reduced by a concentric fibro-mucoid intimal thickening, which would be in keeping with the circulatory findings and the absence of response to cortisone.

Although many of the patients investigated had clinical features suggestive of rheumatoid disease and had a positive sheep cell agglutination test, only those who had typical rheumatoid arthritis responded significantly to cortisone therapy. Whatever the pathological process may be in the other patients with limb pains, joint stiffness, reduced peripheral circulation, and a tendency to sclerosis and atrophy of the extremities, it does not appear to be greatly influenced by the short-term administration of cortisone. Long-term cortisone therapy might, however, be worthy of trial in those patients in whom the reactive hyperaemia timing test shows a delay of less than 10 seconds.

\section{Summary}

(1) The peripheral vascular response to short courses of cortisone has been studied by a heat flow technique in 22 patients suffering from rheumatoid disease, systemic sclerosis, and other related syndromes in which digital blood flow is reduced.

(2) During cortisone therapy there was a marked increase of digital blood flow in patients who experienced relief of joint pain and stiffness and in whom the reactive hyperaemia time was less than 5 seconds.

(3) The differential sheep cell agglutination test was positive in fourteen of the 22 patients investigated, but the presence of a positive test was not specially associated with a good symptomatic or on vascular response to cortisone.

(4) After the withdrawal of cortisone the digital $\stackrel{\vec{F}}{+}$ blood flow usually fell to below pre-treatment levels.

The cortisone used in these studies was provided by $\frac{\bar{\sigma}}{\overline{0}}$ the Medical Research Council.

\section{REFERENCES}

Ball, J. (1950). Lancet, 2, 520.

Barcroft, H., Gaskell, P., Shepherd, J. T., and Whelan, R. F. (1954). J. Physiol. (Lond.), 123, 443.

Beattie, J. W., and Woodmansey, A. (1953). Annals of the Rheumatic Diseases, 12, 43.

Catchpole, B. N., and Jepson, R. P. (1954). Circulation, 9, 408.

Hatfield, H. S. (1950). J. Physiol. (Lond.), 111, 10P.

Hines, E. A., Wakim, K. G., Roth, G. M., and Kierland, R. R. (1950). J. Lab. clin. Med., 36, 834.

Hollander, J. L., Stoner, E. K., Brown, E. M., and De Moor, P. (1951). J. clin. Invest., 30, 701.

Janus, O. (1952). Unpublished observations.

Pickering, G. W. (1933). Brit. med. J., 2, 1106.

Pickering, G. W. (1933). Brit. med. J., 2,
Vulliamy, D. G. (1952). Lancet, 2, 1248 .

Woodmansey, A. (1951). Annals of the Rheumatic Diseases, 10, 65. N

Effet vasculaire périphérique de la cortisone dans l'arthrite rhumatismale, la sclérodermie et les affections apparentées RÉSUMÉ

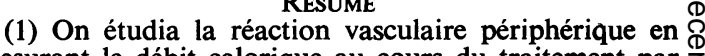
mesurant le débit calorique au cours du traitement par $\frac{}{3}$ la cortisone de peu de durée chez 22 malades atteints de maladie rhumatismale, de sclérodermie et d'autres syndromes apparentés dans lesquels le débit sanguion $\vec{\theta}$ digital est réduit.

(2) $\mathrm{Au}$ cours du traitement par la cortisone on not une augmentation appréciable du débit sanguin digita chez les malades qui éprouvèrent un soulagement de douleur et de la rigidité articulaire et chez qui le temps de l'hyperémie réactive fut inférieur à 5 secondes.

(3) Le test différentiel d'agglutination des cellules de ڤ mouton fut positif chez quatorze sur les 22 malades $\mathbb{Q}$ étudiés, mais la présence d'un test positif ne fut pas associée particulièrement à une réaction symptomatique $\overline{\underline{0}}$ ou vasculaire favorable à la cortisone.

(4) Après l'arrêt du traitement par la cortisone le $\underset{\partial}{\partial}$ débit sanguin digital tombait généralement en dessous du niveau existant avant le traitement.

Efecto vascular periférico de la cortisona en la artritis reumatoide, esclerodermia y afecciones afines Sumario

(1) Se estudió la reacción vascular periférica por el $\stackrel{\partial}{\varnothing}$ método calorimétrico en el curso del corto tratamiento 3 con cortisona en 22 enfermos con artritis reumatoide, esclerodermia y otros síndromes afines en los cuales la corriente sanguínea está reducida.

(2) En el curso del tratamiento con cortisona se notó un aumento apreciable de la corriente sangúnea digital en los enfermos que sintieron un alivio del dolor y de la $\mathrm{N}$ rigidez articular y en los cuales el tiempo de la hiperemia reactiva fué inferior a 5 segundos.

(3) El test diferencial de aglutinación de células de oveja fué positivo en catorce de los 22 enfermos estudi- $\sigma$ ados, pero la presencia de un test positivo no fué especialmente asociada a una reacción sintomática vascular favorable a la cortisona.

(4) Al retirar la cortisona la corriente sanguínea digital cafa generalmente debajo del nivel de antes del tratamiento. 